\title{
Reduced Striatal Dopamine Transporter Density in Abstinent Methamphetamine and Methcathinone Users: Evidence from Positron Emission Tomography Studies with $\left[{ }^{11} \mathrm{C}\right] \mathrm{WIN}-35,428$
}

\author{
Una D. McCann, ${ }^{1}$ Dean F. Wong, ${ }^{2}$ Fuji Yokoi, ${ }^{2}$ Victor Villemagne, ${ }^{2}$ Robert F. Dannals, ${ }^{2}$ and \\ George A. Ricaurte ${ }^{3}$ \\ 1 Unit on Anxiety Disorders, Biological Psychiatry Branch, National Institute of Mental Health, Intramural Research \\ Program, Bethesda, Maryland 20892, and 2Department of Radiology, Division of Nuclear Medicine and ${ }^{3}$ Department of \\ Neurology, The Johns Hopkins Medical Institutions, Baltimore, Maryland 21224
}

\begin{abstract}
Methamphetamine and methcathinone are psychostimulant drugs with high potential for abuse. In animals, methamphetamine and related drugs are known to damage brain dopamine (DA) neurons, and this damage has recently been shown to be detectable in living nonhuman primates by means of positron emission tomography (PET) with $\left[{ }^{11} \mathrm{C}\right] \mathrm{WIN}-35,428$, a DA transporter (DAT) ligand. The present studies determined whether living humans with a history of methamphetamine or methcathinone abuse showed evidence of lasting decrements in brain DAT density. PET studies were performed in 10 control subjects, six abstinent methamphetamine users, four abstinent methcathinone users, and three patients with Parkinson's disease (PD). On average, subjects had abstained from amphetamine use for $\sim 3$ years. Before PET studies, all subjects underwent urine and blood toxicology screens to rule out recent
\end{abstract}

Recent epidemiological surveys indicate that the use of psychostimulant drugs of the amphetamine class is sharply on the rise (Kozel, 1997). Two of these psychostimulants, methamphetamine ("speed", "crystal meth", or "crank") and methcathinone ("cat"), are easily and inexpensively synthesized from the legal substance ephedrine (Goldstone, 1993; Calkins et al., 1995; Tolliver, 1995), prompting some profit-minded individuals to set up lucrative clandestine portable drug factories for the manufacture of large quantities of these substances (U.S. Department of Justice, 1994). Outbreaks of methcathinone abuse have occurred during this decade in Wisconsin and Michigan (Emerson and Cisek, 1993; Calkins et al., 1995; Tolliver, 1995). Much larger epidemics of methamphetamine abuse have occurred over the years in the United States (Miller and Hughes, 1994), as well as abroad (Brill and Hirose, 1969; Kall, 1997; Suwaki et al., 1997). Currently, illicit use of methamphetamine appears to be particularly prevalent in the western United States (Kozel, 1997; Lukas, 1997).

Methamphetamine and methcathinone may pose risks to users beyond those associated with drug abuse and dependence. In particular, both of these drugs are neurotoxic to brain dopamine

Received July 17, 1998; accepted July 29, 1998.

This work was supported by Public Health Service Grants DA05707, DA06275 (G.A.R.), and DA09482 (D.F.W.) and by the National Institute of Mental Health, Intramural Research Program (U.D.M.).

Correspondence should be addressed to Dr. George A. Ricaurte, Department of Neurology, The Johns Hopkins Medical Institutions, 5501 Bayview Drive, Room 5B71E, Baltimore, MD 21224.

Copyright (C) 1998 Society for Neuroscience $\quad 0270-6474 / 98 / 188417-06 \$ 05.00 / 0$ drug use. Compared with controls, abstinent methamphetamine and methcathinone users had significant decreases in DAT density in the caudate nucleus $(-23$ and $-24 \%$, respectively) and putamen ( -25 and $-16 \%$, respectively). Larger decreases in DAT density were evident in patients with PD (47 and $68 \%$ in caudate and putamen, respectively). Neither methamphetamine nor methcathinone users showed clinical signs of parkinsonism. Persistent reductions of DAT density in methamphetamine and methcathinone users are suggestive of loss of DAT or loss of DA terminals and raise the possibility that as these individuals age, they may be at increased risk for the development of parkinsonism or neuropsychiatric conditions in which brain DA neurons have been implicated.

Key words: amphetamines; methamphetamine; dopamine; neurotoxicity; dopamine transporter; parkinsonism
(DA) and serotonin (5-HT) neurons in animals (Seiden and Ricaurte, 1987; Gibb et al., 1994; Gygi et al., 1996; Sparago et al., 1996; Frey et al., 1997). After administration of methamphetamine or methcathinone, animals develop long-lasting decreases in brain DA and 5-HT axonal markers, including the neurotransmitters themselves (i.e., DA and 5-HT), their rate-limiting synthetic enzymes (tyrosine hydroxylase and tryptophan hydroxylase), and their transporter sites (Seiden et al., 1976; Wagner et al., 1979, 1980a,b, 1983; Hotchkiss and Gibb, 1980; Levine et al., 1980; Steranka and Sanders-Bush, 1980; Bakhit et al., 1981; Woolverton et al., 1989; Gygi et al., 1996; Sparago et al., 1996; Frey et al., 1997). In addition, silver-staining methods show evidence of striatal axon terminal degeneration after the administration of methamphetamine (Ricaurte et al., 1982, 1984) or methcathinone (Sparago et al., 1996). DA cell body loss has been reported in mice (Sonsalla et al., 1996; Hirata and Cadet, 1997) but not in rats (Ricaurte et al., 1982) or monkeys (Woolverton et al., 1989) previously treated with high doses of methamphetamine.

In animals, lower doses of amphetamine and methamphetamine produce neurotoxicity if administered repeatedly at short intervals (e.g., two to four times at $2 \mathrm{hr}$ intervals) (Sonsalla et al., 1989; Melega et al., 1993). Some methamphetamine and methcathinone users ("bingers") self-administer the drugs repeatedly, typically multiple times daily and often for several sequential days, during which time they forgo both food and sleep (Miller and Hughes, 1994; Calkins et al., 1995). If one considers differences in body mass and surface area and uses interspecies scaling methods to calculate equivalent human doses (Mordenti and 
Chappell, 1989; Chappell and Mordenti, 1991), doses known to be neurotoxic in animals often overlap with those used by humans (Villemagne et al., 1998), raising concern over long-term effects in humans.

There have been no studies evaluating living humans with a history of methamphetamine or methcathinone abuse for possible long-term changes in brain DA neurons, primarily because of difficulties inherent in evaluating the status of chemically defined populations of neurons in the living human brain. With the advent of positron emission tomography (PET) and neuronspecific radioligands, it is now possible to assess the status of DA neurons in living primates. Indeed, it has been possible recently to detect methamphetamine-induced DA neurotoxicity in living baboons by means of PET imaging with $\left[{ }^{11} \mathrm{C}\right] \mathrm{WIN}-35,428$ (Villemagne et al., 1998), a highly selective DA transporter (DAT) ligand that is also known as $2 \beta$-carbomethoxy-3 $\beta$-(4-fluorophenyl)- $[N$ $\left[{ }^{11} \mathrm{C}\right]$ methyl]tropane or $\left[{ }^{11} \mathrm{C}\right] \mathrm{CFT}$ (Madras et al., 1989; Canfield et al., 1990; Kaufman et al., 1991).

The purpose of the present study was to determine whether lasting decrements in striatal DAT density were evident in abstinent users of methamphetamine and methcathinone, studied by means of PET imaging with $\left[{ }^{11} \mathrm{C}\right] \mathrm{WIN}-35,428$. In particular, it was hypothesized that methamphetamine and methcathinone users, like patients with Parkinson's disease (PD), would demonstrate decreased density of $\left[{ }^{11} \mathrm{C}\right] \mathrm{WIN}-35,428$ binding, reflecting possible damage to brain dopaminergic axons and terminals.

\section{MATERIALS AND METHODS}

Subjects. Ten control subjects, six methamphetamine users, four methcathinone users, and three patients with early PD participated in these studies (Table 1). Methamphetamine subjects were recruited from drug rehabilitation treatment groups. Methcathinone users were identified through the Drug Enforcement Administration while they were still incarcerated for drug-related charges. All methamphetamine and methcathinone users had used other recreational drugs also (cannabis, lysergic acid diethylamide, benzodiazepines, cocaine, and alcohol) but listed methamphetamine or methcathinone as their drug of choice and greatest use. Control subjects and patients with newly diagnosed PD (Hoehn and Yahr stage II) were recruited from a university normal volunteer office and an outpatient neurology clinic, respectively. Subjects were in good general health (aside from their index condition), as determined by medical history, physical exam, electrocardiogram, and blood and urine chemistries, including a complete blood count, liver and thyroid function tests, hepatitis and human immunodeficiency virus screens, and routine urinalyses. Detailed neurological exams were performed by a neurologist experienced with movement disorders, particularly PD. None of the PD patients had been treated with anti-parkinsonian medications, because they were newly diagnosed. Furthermore, none of the subjects were on neuroleptics, Ritalin, or other therapeutic drugs at the time of PET scanning. Written informed consent was given by all study participants, who agreed to refrain from any illicit drug use for at least 2 weeks before

\begin{tabular}{|c|c|c|c|c|}
\hline & Control subjects & MA users & MC users & PD patients \\
\hline$n$ & 10 & 6 & 4 & 3 \\
\hline $\begin{array}{l}\text { Age (yr) } \\
\text { (range) }\end{array}$ & $\begin{array}{c}30.5 \pm 10.0 \\
(18-48)\end{array}$ & $\begin{array}{c}37.5 \pm 8.1 \\
(26-45)\end{array}$ & $\begin{array}{c}31.2 \pm 5.6 \\
(26-39)\end{array}$ & $\begin{array}{c}53.3 \pm 10.4^{*} \\
(45-65)\end{array}$ \\
\hline $\operatorname{Sex}(M / F)$ & $4 / 6$ & $3 / 3$ & $2 / 2$ & $2 / 1$ \\
\hline
\end{tabular}

$\overline{\text { Values represent the mean } \pm \mathrm{SD} \text {, with ranges shown in parentheses. } n=\text { Number }}$ of subjects.

*Designates significant difference from all other groups (ANOVA and post hoc Duncan's multiple range test; $p<0.05$ ). MA, Methamphetamine; MC, methcathinone; PD, Parkinson's disease. study. All subjects underwent blood and urine drug screens for therapeutic and illicit drugs before PET scanning.

Drug use history. Information about drug use was obtained in several ways: (1) a preliminary telephone interview; (2) a questionnaire that asked about the number of times methamphetamine or methcathinone had been used, the typical dose used, the frequency of use, the last time of use, and the highest dose of methamphetamine or methcathinone taken; and (3) a standardized drug history questionnaire (drug history section of the Addiction Severity Index).

Drug screens. Serum and urine samples were screened for drugs of abuse by Enzyme Multiplied Immunoassay Technique, a reliable detection method for identifying recent use of amphetamines, barbiturates, benzodiazepine metabolites, cocaine and metabolites, opiates, phencyclidine, and tetrahydrocannabinol.

Preparation of $\left[{ }^{11} \mathrm{C}\right] W I N-35,428$. $\left[{ }^{11} \mathrm{C}\right] \mathrm{W}$ IN-35,428 was synthesized as described previously (Dannals et al., 1993). The average specific activity of the final product calculated at the end of synthesis was $>2000 \mathrm{mCi}$ / $\mu \mathrm{mol}$ and averaged $6,000 \mathrm{mCi} / \mu \mathrm{mol}$ in the present studies.

PET scans. PET studies with $\left[{ }^{11} \mathrm{C}\right] \mathrm{WIN}-35,428$ were performed as described previously (Wong et al., 1993), with minor modification. Briefly, $\sim 20 \mathrm{mCi}$ of $\left[{ }^{11} \mathrm{C}\right] \mathrm{WIN}-35,428$ was administered intravenously. Thereafter, a series of 50 PET images were acquired. The scanning image protocol consisted of 50 scan acquisitions, starting from $15 \mathrm{sec}$ and increasing to $6 \mathrm{~min}$ in length over a $90 \mathrm{~min}$ period. Images were acquired on the General Electric $4096^{\text {Plus }}$ whole-body PET scanner and were preceded by a $10 \mathrm{~min}$ attenuation scan using a rotating germanium 68 source. Total protein, albumin, globulin, and protein electrophoresis were determined for each subject before PET studies. All analyses were performed on data corrected for radioactive decay. Blood samples for measurement of $\left[{ }^{11} \mathrm{C}\right] \mathrm{WIN}-35,428$ metabolites were obtained from an indwelling arterial line at 5, 15, 30, 60, and 90 min after injection. Images were reconstructed using a ramped filtered back projection and were smoothed to a final resolution (5-6 $\mathrm{mm}$ in plane resolution, $6-7 \mathrm{~mm}$ $z$-axis). Regions of interest were outlined for the caudate, putamen, and cerebellum by an investigator unaware of the subjects' histories. Adequate anatomical localization was ensured by using the Register program for magnetic resonance imaging-PET coregistration (Evans et al., 1991). Results were analyzed by using a three-compartment receptor model (Wong et al., 1993), estimating the four kinetic parameters, and computing a $k_{3} / k_{4}$ ratio, defined as binding potential (BP), to obtain a measure of $\left[{ }^{11} \mathrm{C}\right] \mathrm{W}$ IN-35,428 binding. In this approach, $k_{1} / k_{2}$ obtained in the cerebellum is used to constrain $k_{1} / k_{2}$ in the striatum (caudate nucleus, putamen), thereby reducing the number of parameters.

Data analysis. Differences in kinetic parameters of $\left[{ }^{11} \mathrm{C}\right] \mathrm{W}$ IN-35,428 binding $\left(k_{3} / k_{4}\right)$ among groups were compared using analysis of covariance (ANCOVA), followed by Duncan's multiple range post hoc comparisons, with age as a covariate. Because our sample size was small, the PET results were also corrected for age before statistical analysis to guard for possible confounding effects of age-related declines in DAT (see Table 3 for method of age correction). Age-corrected kinetic parameters were compared using ANOVA, followed by Duncan's multiple range post hoc comparisons. Data analysis was done using the Statistical Program for the Social Sciences (SPSS for Windows, Release 6). All tests were two-tailed, and significance was set at $p<0.05$.

\section{RESULTS}

\section{Demographics}

Subjects were well matched with regard to gender. However, as shown in Table 1 , there were significant age differences $\left(F_{(3,19)}=\right.$ 5.3; $p=0.008)$, with post hoc tests indicating that PD patients were older than methamphetamine, methcathinone, and control subjects.

\section{Drug use}

Characteristics of drug use in methamphetamine and methcathinone users are summarized in Table 2. Control subjects and patients with PD had no history of drug abuse or dependence. All methamphetamine and methcathinone subjects tested negative for recent drug use and reported having abstained from amphetamine use for $\sim 3$ years (Table 2 ). 
Table 2. Characteristics of drug use in methamphetamine and methcathinone users

Methamphetamine

\begin{tabular}{|c|c|c|c|c|c|c|c|c|c|}
\hline Subject & Age (yr) & Sex & Weight & Usual amount & Heaviest binge & Route & Duration of use & Last use & PET \\
\hline 1 & 26 & $\mathrm{M}$ & $86.3 \mathrm{~kg}$ & $1 / 4-1 / 2 \mathrm{~g} / \mathrm{d}$ & $1 \frac{1 / 4}{\mathrm{~g}}$ in $1 \mathrm{~d}$ & snorted/smoked & 3 years & $8 / 95$ & $12 / 95$ \\
\hline 2 & 45 & M & $85.6 \mathrm{~kg}$ & $1 / 4 \mathrm{~g} / \mathrm{d}$ & $1-2 \mathrm{~g}$ in $1 \mathrm{~d}$ & snorted/IV & 20 years & $7 / 93$ & $1 / 97$ \\
\hline 3 & 45 & M & $67.6 \mathrm{~kg}$ & $1 / 4-1 / 2 \mathrm{~g} / \mathrm{d}$ & $1 / 2-1 \mathrm{~g}$ in $1 \mathrm{~d}$ & snorted & 3 years & $5 / 93$ & $2 / 97$ \\
\hline 4 & 41 & $\mathrm{~F}$ & $60.8 \mathrm{~kg}$ & $1 / 4 \mathrm{~g} / \mathrm{d}$ & $1 / 2 \mathrm{~g}$ in $1 \mathrm{~d}$ & snorted/smoked & 10 years & $12 / 93$ & $4 / 97$ \\
\hline 5 & 39 & $\mathrm{~F}$ & $74.3 \mathrm{~kg}$ & $31 / 2 \mathrm{~g} / \mathrm{d}$ & $3 \frac{1}{2} \mathrm{~g}$ in $1 \mathrm{~d}$ & snorted & 12 years & $3 / 91$ & $8 / 96$ \\
\hline 6 & 29 & $\mathrm{~F}$ & $58.6 \mathrm{~kg}$ & $1 / 4 \mathrm{~g} / \mathrm{d}$ & $8 \mathrm{~g}$ in $1 \mathrm{~d}$ & snorted/smoked/IV & $18-20$ years & $11 / 96$ & $4 / 97$ \\
\hline \multicolumn{10}{|c|}{ Methcathinone } \\
\hline Subject & Age (yr) & Sex & Weight & Usual amount & Heaviest binge & Route & Duration of use & Last use & PET \\
\hline 1 & 29 & $\mathrm{~F}$ & $62.6 \mathrm{~kg}$ & $2 \mathrm{~g} / \mathrm{d}$ & $61 / 4 \mathrm{~g}$ in $1 \mathrm{~d}$ & oral/snorted & 3 years & $4 / 93$ & $7 / 95$ \\
\hline 2 & 26 & M & $75.9 \mathrm{~kg}$ & $31 / 2 \mathrm{~g} / \mathrm{d}$ & $7 \mathrm{~g} / \mathrm{d} / 41 \mathrm{~d}$ & oral/snorted & 3 years & $4 / 92$ & $7 / 95$ \\
\hline 3 & 30 & M & $78.8 \mathrm{~kg}$ & $1 \mathrm{~g} / \mathrm{d}$ & $7 \mathrm{~g}$ in $4 \mathrm{~d}$ & snorted & 2 years & $1 / 93$ & $10 / 95$ \\
\hline 4 & 38 & $\mathrm{~F}$ & $60.8 \mathrm{~kg}$ & $1-3 \mathrm{~g} / \mathrm{d}$ & $4 \mathrm{~g}$ in $1 \mathrm{~d}$ & snorted & 3 years & $3 / 93$ & $8 / 96$ \\
\hline
\end{tabular}

Estimated amounts of drug use are expressed in grams (g). IV, Intravenous use.

\section{PET imaging with $\left[{ }^{11} \mathrm{C}\right] \mathrm{WIN}-35,428$ Caudate nucleus}

Marked accumulation of $\left[{ }^{11} \mathrm{C}\right] \mathrm{WIN}-35,428$ was observed in the caudate nucleus, a brain region with a high density of DATs (Fig. 1 , Table 3 ). ANCOVA, with age as a covariate, revealed significant differences in mean $\left[{ }^{11} \mathrm{C}\right] \mathrm{WIN}-35,428 \mathrm{BP}$ in the caudate nuclei of the four subject groups $\left(F_{(3,18)}=4.97 ; p=0.039\right)$. Post hoc testing indicated that relative to control subjects, all other subject groups had significantly lower mean caudate $\left[{ }^{11} \mathrm{C}\right] \mathrm{WIN}$ 35,428 BP values (Table 3 ). Although patients with early PD had the lowest $\left[{ }^{11} \mathrm{C}\right] \mathrm{WIN}-35,428 \mathrm{BP}$ of all four subject groups (Table 3), differences between patients with PD and methamphetamine and methcathinone users did not reach statistical significance. BP values first adjusted for age (see Table 3 legend for method of age adjustment) and then compared by ANOVA (without covarying for age) showed similar differences (Table 3).

\section{Putamen}

As in the caudate nucleus, there was marked accumulation of $\left[{ }^{11} \mathrm{C}\right] \mathrm{WIN}-35,428$ in the putamen of control subjects. ANCOVA revealed significantly lower mean $\left[{ }^{11} \mathrm{C}\right] \mathrm{WIN}-35,428 \mathrm{BP}$ values in the putamen of all three experimental groups compared with controls $\left(F_{(3,18)}=5.53 ; p=0.007\right)$. In contrast to findings in the caudate nucleus, patients with early PD had significantly lower mean putamen $\left[{ }^{11} \mathrm{C}\right] \mathrm{WIN}-35,428$ binding than all other subject groups, differing significantly from methamphetamine and methcathinone users, as well as control subjects (Fig. 1, Table 3). The greater reduction in $\left[{ }^{11} \mathrm{C}\right] \mathrm{WIN}-35,428 \mathrm{BP}$ in the putamen compared with the caudate nucleus is in keeping with previous observations of greater DA terminal loss in the putamen than in the caudate of patients with PD (Kish et al., 1988; Tedroff et al., 1988; Kaufman and Madras, 1991; Frost et al., 1993). Comparison of age-adjusted BP values using ANOVA showed similar differences, except that the difference between methcathinone subjects and controls did not achieve statistical significance (Table 3 ).

\section{DISCUSSION}

The results of the present study are the first to document a reduced density of striatal $\left[{ }^{11} \mathrm{C}\right] \mathrm{WIN}-35,428$-labeled DAT sites in living humans with a history of methamphetamine and methcathinone abuse. Like patients with early PD, former methamphetamine and methcathinone users have decreases in striatal

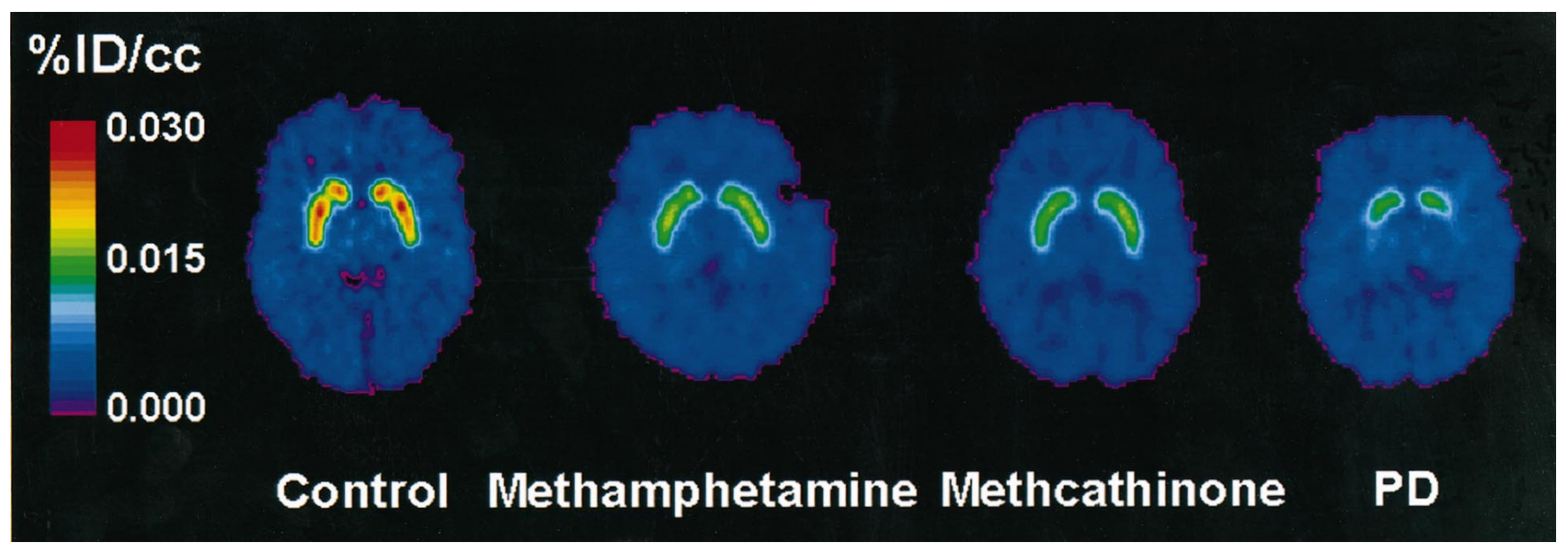

Figure 1. PET images showing accumulation of $\left[{ }^{11} \mathrm{C}\right] \mathrm{WIN}-35,428$ in the striatum in a control subject, an abstinent methamphetamine subject, an abstinent methcathinone subject, and a PD patient $70-90$ min after injection of $\left[{ }^{11} \mathrm{C}\right] \mathrm{WIN}-35,428$. 
Table 3. Binding potentials of $\left[{ }^{11} \mathrm{C}\right] \mathrm{WIN}-35,428$ in the caudate nucleus and putamen of control subjects, abstinent methamphetamine users, abstinent methcathinone users, and Parkinson's disease patients

\begin{tabular}{|c|c|c|c|}
\hline & $n$ & Caudate nucleus $\left(k_{3} / k_{4}\right)$ & Putamen $\left(k_{3} / k_{4}\right)$ \\
\hline Control & 10 & $7.5 \pm 1.7 \quad(8.7 \pm 1.6)$ & $(8.3 \pm 1.4)$ \\
\hline Methamphetamine & 6 & $5.8 \pm 1.0^{*}(7.0 \pm 1.2)^{*}$ & $5.5 \pm 0.9^{*} \quad(6.7 \pm 0.9)^{*}$ \\
\hline Methcathinone & 4 & $5.7 \pm 0.9^{*}(6.7 \pm 1.3)^{*}$ & $6.1 \pm 0.4^{*} \quad(7.1 \pm 0.6)$ \\
\hline Parkinson's disease & 3 & $4.0 \pm 0.9^{*}(5.4 \pm 1.2)^{*}$ & $2.3 \pm 0.4^{* *}(3.1 \pm 0.6)^{* *}$ \\
\hline
\end{tabular}

$k_{3} / k_{4}$ or binding potential (BP) values were determined using a three-compartment model and represent caudate nucleus bound/free and putamen bound/free $\left[{ }^{11} \mathrm{C}\right] \mathrm{WIN}-35,428$, respectively. The age adjustment was made using PET imaging data from van Dyck et al. (1995) suggesting that DAT density in the human striatum declines with age at the rate of $0.8 \% /$ year, assuming no decline during the first 10 years of life. BP values were corrected for age using the following equation: [(age 10 in years $) \times 0.8 \%$ DAT decline per year +100$] \times$ [uncorrected BP value], recognizing that the $0.8 \% /$ year estimate of DAT decline may be somewhat high (Tedroff et al., 1988; Volkow et al., 1994). Values shown are the mean \pm SD. $n=$ Number of subjects. *Designates significant difference from control group; **designates significant difference from all other groups. Values in parentheses represent BP values corrected for age.

$\left[{ }^{11} \mathrm{C}\right]$ WIN-35,428 binding, although the decreases in methamphetamine and methcathinone subjects are not as pronounced as those in PD patients (Fig. 1, Table 3). When considered with results of recent preclinical studies directly documenting the validity of PET imaging with $\left[{ }^{11} \mathrm{C}\right] \mathrm{WIN}-35,428$ for detecting methamphetamine-induced DA neurotoxicity in the living baboon brain (Villemagne et al., 1998), the present findings suggest that lasting reductions in DAT density in methamphetamine and methcathinone users may be related to damage of striatal DA axons and axon terminals.

An important question raised by the present findings is whether the lasting reduction in striatal DAT density here documented in abstinent methamphetamine and methcathinone users might not reflect a neuroadaptive process rather than DA neurotoxicity. Given the large body of evidence directly documenting the DA neurotoxic potential of methamphetamine in every animal species thus far examined, including nonhuman primates (Seiden and Ricaurte, 1987; Woolverton et al., 1989; Villemagne et al., 1998), we tend to favor the view that DA neurotoxicity may be involved. This view is also supported by the observation that similar, although more severe, decreases in $\left[{ }^{11} \mathrm{C}\right] \mathrm{W}$ IN-35,428 binding are evident in the striata of patients with PD (Kaufman and Madras, 1991; Frost et al., 1993; Table 3), a neurodegenerative disorder in which nigrostriatal DA neuronal degeneration is well documented (Hornykiewicz, 1966; Kish et al., 1988). This support notwithstanding, it must be recognized that decreases in DAT density could be related to a neuroadaptive process, perhaps compensating for a depletion of brain DA not associated with actual DA nerve terminal degeneration. Indeed, there are several reports of changes in DAT density after a variety of pharmacological manipulations that do not involve DA neurotoxicity (Cerruti et al., 1994; Koff et al., 1994; Tella et al., 1997; Malison et al., 1998). To our knowledge, however, none of the reported changes in DAT density are in the direction or as long-lasting as the reductions herein documented.

Another important factor to consider is the potential confounding influence of age on $\left[{ }^{11} \mathrm{C}\right] \mathrm{W}$ IN-35,428 binding. In particular, subjects with a history of methamphetamine abuse were somewhat (although not significantly) older than controls, seeming to parallel losses of DAT binding observed by PET. Although agerelated reductions in the DAT are known to occur (Evans et al., 1991; Volkow et al., 1994; van Dyck et al., 1995; Frey et al., 1996), the reported age-related decreases are not of the degree observed in the present study nor do they occur from ages 30 to 37 , the mean ages of methamphetamine and control subjects, respectively. Furthermore, like abstinent methamphetamine users, ab- stinent methcathinone users had decreased [ $\left[{ }^{11} \mathrm{C}\right]$ WIN-35,428 binding, yet they were no different in age from the control subjects. Finally, decrements in DAT are also evident in agecorrected PET data (Table 3) and are similar to those in baboons treated with doses and regimens of methamphetamine comparable to those used by several of the subjects in the present study (Villemagne et al., 1998).

The present results may initially appear to be in conflict with those of Wilson and colleagues (1996a), who performed postmortem studies in chronic methamphetamine users and concluded that no DA neurotoxicity had occurred, despite a loss of several brain DA neuronal markers, including the DAT. That conclusion was based primarily on the observation that levels of dihydroxyphenylalanine decarboxylase (DDC) and the vesicular monoamine transporter (VMAT) were normal in methamphetamine users, whereas in PD they were reduced. Although DDC and VMAT levels can be useful for detecting severe DA cell loss, such as in PD (Hornykiewicz, 1966; Tedroff et al., 1988; Wilson et al., 1996b), they appear to be less sensitive for detecting milder degrees of nigrostriatal DA injury, such as that in olivopontocerebellar atrophy (Zhong et al., 1995; Wilson et al., 1996b). In the present study, a less profound reduction in DAT density was found in methamphetamine and methcathinone subjects than in PD patients (Table 3), possibly accounting for the apparently normal DDC and VMAT levels found by Wilson and colleagues (1996a) in methamphetamine users. Moreover, baboons treated with dose regimens of methamphetamine comparable to those used by subjects in the present study have similar PET findings to those described herein (Villemagne et al., 1998). Because postmortem studies of these animals revealed loss of a variety of dopaminergic neuronal markers, including VMAT and DAT, it is possible that differences in drug use patterns (e.g., binge use vs chronic maintenance drug use) underlie the differences between this study and that by Wilson and colleagues (1996a). Additional neuroimaging studies with radioligands that label other elements of the DA neuron [e.g., the VMAT, which can be imaged with $\left[{ }^{11} \mathrm{C}\right]$ dihydrotetrabenazine (Frey et al., 1996; Gilman et al., 1996)] should shed further light on this important issue.

It should be noted that methamphetamine and methcathinone users that participated in this study had a history of polydrug use, raising the possibility that other drugs of abuse may have been responsible for changes seen in PET images. However, none of the other drugs used by these individuals are known to be DA neurotoxins or to produce lasting effects on DAT density, mitigating the likelihood of this possibility. Another potential drawback of the present study is the fact that previous drug histories 
were obtained from subjects using retrospective self-reports. This is an inherent difficulty in studies of individuals who use illegal substances. Nevertheless, although the accuracy of drug histories (and the purity of the various drugs used) cannot be verified retrospectively, methcathinone users in this study were members of methcathinone drug distribution rings. The basis for their arrest and, in many cases incarceration, was the seizure of large amounts of methcathinone, as well as the tools necessary for their manufacture. Thus, although the purity of other drugs used could be questioned, the purity of methcathinone available to them is certain. Finally, one could question the use of BP as a measure of DAT density, because alteration in this parameter could be caused by changes in either $B_{\max }$ or $K_{\mathrm{d}}$. However, $K_{\mathrm{d}}$ does not change in PD, and experimental studies indicate that long-term effects of methamphetamine on DA transporters are related to decreases in $B_{\max }$ rather than $K_{\mathrm{d}}$ (Wagner et al., 1980a; Seiden and Ricaurte, 1987; Frey et al., 1997).

In summary, results from the present study are the first to document a persistent decrease in $\left[{ }^{11} \mathrm{C}\right] \mathrm{W}$ IN-35,428-labeled brain DA transporters in abstinent human methamphetamine and methcathinone users. Because similar persistent decreases in $\left[{ }^{11} \mathrm{C}\right] \mathrm{WIN}-35,428$ binding are evident in baboons with known DA neurotoxicity (Villemagne et al., 1998), the present results raise the possibility of brain DA neurotoxicity in human methamphetamine and methcathinone users, although a neuroadaptive process is also conceivable. Notably, decrements in $\left[{ }^{11} \mathrm{C}\right] \mathrm{WIN}-35,428$ binding in abstinent methamphetamine and methcathinone users were less severe that those found in patients with early PD and were not associated with overt neurological or psychiatric illness. Longitudinal studies are therefore needed to determine whether individuals with a history of methamphetamine and methcathinone use are at an increased risk for developing parkinsonism or other neuropsychiatric conditions in which brain DA deficiency has been implicated.

\section{REFERENCES}

Bakhit C, Morgan MA, Peat MA, Gibb JW (1981) Long-term effects of methamphetamine on the synthesis and metabolism of 5 -hydroxytryptamine in various regions of the rat brain. Neuropharmacology 20:1135-1140.

Brill H, Hirose T (1969) The rise and fall of a methamphetamine epidemic. Semin Psychiatry 1:179-213.

Calkins RF, Aktan GB, Hussain KL (1995) Methcathinone: the next illicit stimulant epidemic? J Psychoact Drugs 27:277-285.

Canfield DR, Spealman RD, Kaufman MJ, Madras BK (1990) Autoradiographic localization of cocaine binding sites by [3H]CFT ([3H]W IN $35,428)$ in the monkey brain. Synapse 6:189-195.

Cerruti C, Pillotte N, Uhl G, Kuhar M (1994) Reduction in dopamine transporter mRNA after cessation of repeated cocaine administration. Mol Brain Res 22:1-4.

Chappell W, Mordenti J (1991) Extrapolation of toxicological and pharmacological data from animals to humans. In: Advances in drug research (Testa B, ed), pp 1-116. San Diego: Academic.

Dannals RF, Neumeyer JL, Milius RA, Ravert HT, Wilson AA, Wagner Jr HN (1993) Synthesis of a radiotracer for studying dopamine uptake sites in vivo using PET: 2b-Carbomethoxy-3b-(4-fluorophenyl)-[N- ${ }^{11} \mathrm{C}$ methyl]tropane $\left(\left[{ }^{11} \mathrm{C}\right] \mathrm{CFT}\right.$ or $\left[{ }^{11} \mathrm{C}\right] \mathrm{W}$ IN 35,428$)$. J Labelled Compd Radiopharm 33:147-152.

Emerson TS, Cisek JE (1993) Methcathinone: A russian designer amphetamine infiltrates the rural midwest. Ann Emerg Med 22:129-135.

Evans AC, Torrescorzo MS, Ku S, Collins L (1991) MRI-PET correlation in three dimensions using a volume-of-interest (VOI) atlas. J Cereb Blood Flow Metab 11:A69-A78.

Frey K, Koeppe R, Kilbourn M, Vander Borght T, Albin R, Gilman S, Kuhl D (1996) Presynaptic monoaminergic vesicles in Parkinson's disease and normal aging. Ann Neurol 40:873-884.

Frey K, Kilbourne M, Robinson T (1997) Reduced striatal vesicular monoamine transporters after neurotoxic but not after behaviorallysensitizing doses of methamphetamine. Eur J Pharmacol 334:273-279.

Frost JJ, Rosier AJ, Reich SG, Smith JS, Ehlers MD, Snyder SH, Ravert HT, Dannals RF (1993) Positron emission tomographic imaging of the dopamine transporter with ${ }^{11} \mathrm{C}$-W IN-35,428 reveals marked declines in mild Parkinson's disease. Ann Neurol 34:423-431.

Gibb JW, Hanson GR, Johnson M (1994) Neurochemical mechanisms of toxicity. In: Amphetamine and its analogs (Cho AK, Segal DS, eds), pp 269-295. San Diego: Academic.

Gilman S, Frey K, Koeppe R, Junck L, Little R, Vander Borght T, Lohman M, Martorello S, Lee L, Jewett D, Kilbourn M (1996) Decreased striatal monoaminergic terminals in olivopontocerebellar atrophy and multiple systems atrophy demonstrated with positron emission tomography. Ann Neurol 40:885-892.

Goldstone MS (1993) "Cat": methcathinone-a new drug of abuse. JAMA 269:2508.

Gygi MP, Gibb JW, Hanson GR (1996) Methcathinone: an initial study of its effects on monoaminergic systems. J Pharmacol Exp Ther 276:1066-1072.

Hirata H, Cadet J (1997) p53-Knockout mice are protected against the long-term effects of methamphetamine on dopaminergic terminals and cell bodies. J Neurochem 69:780-790.

Hornykiewicz O (1966) Dopamine (3-hydroxytyramine) and brain function. Pharmacol Rev 18:925-965.

Hotchkiss AJ, Gibb JW (1980) Long-term effects of multiple doses of methamphetamine on tryptophan hydroxylase and tyrosine hydroxylase activity in rat brain. J Pharmacol Exp Ther 214:257-262.

Kall K (1997) Amphetamine abuse in Sweden. In: Amphetamine misuse (Klee H, ed), pp 215-233. The Netherlands: Harwood Academic.

Kaufman MJ, Madras BK (1991) Severe depletion of cocaine recognition sites associated with the dopamine transporter in Parkinson's disease striatum. Synapse 9:43-49.

Kaufman MJ, Spealman RD, Madras BK (1991) Distribution of cocaine recognition sites in monkey brain. I. In vitro autoradiography with [3H]CFT. Synapse 9:177-187.

Kish S, Shannak K, Hornykiewicz O (1988) Uneven pattern of dopamine loss in the striatum of patients with Parkinson's disease. N Engl J Med 318:867-880.

Koff JM, Shuster L, Miller G (1994) Chronic cocaine administration is associated with behavioral sensitization and time-dependent changes in striatal dopamine transporter binding. J Pharmacol Exp Ther 268:277-292.

Kozel N (1997) Epidemiologic trends in drug abuse, Vol 1. National Institute on Drug Abuse, NIH Publication No.97-4204.SS.

Levine MS, Hull CD, Garcia-Rill E, Erinoff L, Buchwald A, Heller A (1980) Long-term decreases in spontaneous firing of caudate neurons induced by methamphetamine in cats. Brain Res 194:263-268.

Lukas SE (1997) Proceedings of the national consensus meeting on the use, abuse and sequelae of abuse of methamphetamine with implications for prevention, treatment and research. DHHS Publication SMA 96-8013. Rockville: MD: USDHHS.

Madras BK, Spealman RD, Fahey MA, Neumeyer JL, Saha JK, Milius RA (1989) Cocaine receptors labeled by $\left[{ }^{3} \mathrm{H}\right]$-b-carbomethoxy-3-b-(4fluorophenyl)-tropan. Mol Pharmacol 36:518-524.

Malison RT, Best SE, van Dyck CH, McCance EF, Wallace EA, Laruelle M, Baldwin RM, Seibyl JP, Price LH, Kosten TR, Innis RB (1998) Elevated striatal dopamine transporters during acute cocaine abstinence as measured by $[123 \mathrm{I}] \beta$-CIT SPECT. Am J Psychiatry 155:832-834.

Melega WP, Yu DC, Raleigh MJ, Huang SC, Phelps ME (1993) FDOPA-PET studies show neurotoxic effects of low-dose amphetamine in monkeys. Soc Neurosci Abstr 19:822.

Miller M, Hughes A (1994) Epidemiology of amphetamine abuse in the United States. Use and abuse of amphetamines in Japan. In: Amphetamine and its analogs (Cho AK, Segal DS, eds), pp 439-457. San Diego: Academic.

Mordenti J, Chappell W (1989) The use of interspecies scaling in toxicokinetics. In: Toxicokinetics in new drug development (Yacobi A, Kelly J, Batra V, eds), pp 42-96. New York: Pergamon.

Ricaurte GA, Guillery RW, Seiden LS, Schuster CR, Moore RY (1982) Dopamine nerve terminal degeneration produced by high doses of methylamphetamine in the rat brain. Brain Res 235:93-103.

Ricaurte GA, Seiden LS, Schuster CR (1984) Further evidence that amphetamines produce long-lasting dopamine neurochemical deficits by destroying dopamine nerve fibers. Brain Res 303:359-364. 
Seiden LS, Ricaurte GA (1987) Neurotoxicity of methamphetamine and related drugs. In: Psychopharmacology - the third generation of progress (Meltzer HY, ed), pp 359-366. New York: Raven.

Seiden LS, Fischman MW, Schuster CR (1976) Long-term methamphetamine induced changes in brain catecholamines in tolerant rhesus monkeys. Drug Alcohol Depend 1:215-219.

Sonsalla P, Nicklas W, Heikkila R (1989) Role for excitatory amino acids in methamphetamine-induced nigrostriatal dopaminergic toxicity. Science 243:398-400.

Sonsalla P, Jochnowitz ND, Zeevalk JD, Oostveen JA, Hall ED (1996) Treatment of mice with methamphetamine produces cell loss in the substantia nigra. Brain Res 738:172-175.

Sparago M, Wlos J, Yuan J, Hatzidimitriou G, Tolliver J, Dal Cason TA, Katz J, Ricaurte G (1996) Neurotoxic and pharmacologic studies on enantiomers of the $N$-methylated analog of cathinone (methcathinone): a new drug of abuse. J Pharmacol Exp Ther 279:1043-1052.

Steranka LR, Sanders-Bush E (1980) Long-term effects of continuous exposure to amphetamine in brain dopamine concentration and synaptosomal uptake in mice. Eur J Pharmacol 65:433-439.

Suwaki H, Fukui S, Konuma K (1997) Methamphetamine abuse in Japan: its 45 year history and the current situation. In: Amphetamine misuse (Klee H, ed), pp 199-214. The Netherlands: Harwood Academic.

Tedroff J, Aquilonious S, Hartvig P (1988) Monoamine reuptake sites in the human brain evaluated in vivo by means of $\left[{ }^{11} \mathrm{C}\right]$ nomifensine and positron emission tomography: the effects of age and Parkinson's disease. Acta Neurol Scand 77:192-201.

Tella SR, Ladenheim B, Cadet JL (1997) Differential regulation of dopamine transporter after chronic self administration of buproprion and nomifensine. J Pharmacol Exp Ther 281:508-513.

Tolliver JM (1995) Methcathinone: a new amphetamine-like drug of abuse. Natl Inst Drug Abuse Res Monogr Ser 153:406.

U.S Department of Justice, Drug Enforcement Administration (1994) Methcathinone (CAT). Drug intelligence bulletin. Washington, D.C.: U.S. Department of Justice, February.

van Dyck CH, Seibyl JP, Malison RT, Laruelle M, Wallace E, Zoghbi SS, Zea-Ponce Y, Baldwin RM, Charney DS, Hoffer PB, Innis RB (1995) Age-related decline in striatal dopamine transporter binding with iodine-123- $\beta$-CITSPECT. J Nucl Med 36:1175-1181.

Villemagne V, Yuan J, Hatzidimitriou G, Mathews W, Dannals R, Musachio J, Finley P, McCann U, Wong DF, Ricaurte GA (1998) Brain dopamine neurotoxicity in baboons treated with doses of methamphetamine comparable to those recreationally abused by humans: evidence from $\left[{ }^{11} \mathrm{C}\right] \mathrm{WIN}-35,428$ positron emission tomography studies and direct in vitro determinations. J Neurosci 18:419-427.

Volkow ND, Fowler JS, Wang GJ, Logan J, Schlyer D, MacGregor R, Hitzemann R, Wolf AP (1994) Decreased dopamine transporters with age in healthy human subjects. Ann Neurol 36:237-239.

Wagner GC, Schuster CR, Seiden LS (1979) Methamphetamineinduced changes in brain catecholamines in rats and guinea pigs. Drug Alcohol Depend 4:435-438.

Wagner GC, Ricaurte GA, Seiden LS, Schuster CR, Miller RJ, Westley J (1980a) Long-lasting depletions of striatal dopamine and loss of dopamine uptake sites following repeated administration of methamphetamine. Brain Res 181:151-160.

Wagner GC, Ricaurte GA, Johansen C, Schuster CR, Seiden LS (1980b) Amphetamine induces caudate dopamine depletions in monkeys. Neurology 30:547-550.

Wagner GC, Lucot JB, Schuster CR, Seiden LS (1983) Alphamethyltyrosine attenuates and reserpine increases methamphetamineinduced neuronal changes. Brain Res 270:285-288.

Wilson JM, Kalasinsky KS, Levey AI, Bergeron C, Reiber G, Anthony RM, Schmunk GA, Shannak K, Haycock JW, Kish SJ (1996a) Striatal dopamine nerve terminal markers in human, chronic methamphetamine users. Nat Med 2:699-703.

Wilson JM, Levey AI, Rajput A, Ang L, Guttman M, Shannak K, Niznik H, Hornykiewicz O, Pifl C, Kish SJ (1996b) Differential changes in neurochemical markers of striatal dopamine nerve terminals in idiopathic Parkinson's disease. Neurology 47:718-728.

Wong DF, Yung BCK, Dannals RF, Shaya EK, Ravert HT, Chen CA Chan B, Folio T, Scheffel U, Ricaurte GA, Neumeyer JL, Wagner HN Jr, Kuhar MJ (1993) In vivo imaging of baboon and human dopamine transporters by positron emission tomography using $\left[{ }^{11} \mathrm{C}\right] \mathrm{W}$ IN-35,428. Synapse 15:130-142.

Woolverton WL, Ricaurte GA, Forno LS, Seiden LS (1989) Long-term effects of chronic methamphetamine administration in rhesus monkeys. Brain Res 486:73-78.

Zhong X, Haycock J, Shannak K, Robitaille Y, Fratkin J, Koeppen A, Hornykiewicz O, Kish S (1995) Striatal dihydroxyphenylalanine decarboxylase and tyrosine hydroxylase protein in idiopathic Parkinson's disease and dominantly inherited olivopontocerebellar atrophy. Mov Disord 10:10-17. 